\section{SOSYAL INOVASYONUN}

\section{VE SOSYAL GİRIŞIMCILİĞìN}

SOSYAL HIZZMET MESLEĞİNIN

\section{GELECEĞİNDEKİ ROLÜ}

\section{Buğra YILDIRIM}

Dr.Öğr. Üyesi, Manisa Celal Bayar

Üniversitesi

Sağlık Bilimleri Fakültesi

Sosyal Hizmet Bölümü

bugra.yildirim@cbu.edu.tr

\section{Tarık TUNCAY}

Prof.Dr., Hacettepe Üniversitesi

İktisadi ve İdari Bilimler Fakültesi

Sosyal Hizmet Bölümü

ttuncay@ hacettepe.edu.tr

Bu çalışmanın küçük bir klsmı 29-31 Mayıs 2017 tarihleri arasinda Ankara'da düzenlenen Uluslararası Sosyal Hizmet Kongresi 2017'de "Sosyal Hizmetin Geleceğinde Sosyal İnovasyon ve Sosyal Girişsimcilik" başlığı ile sözel bildiri olarak sunulmuştur.

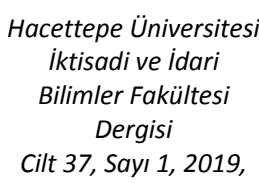

s. $169-187$ 


\section{THE ROLE OF SOCIAL}

\section{INNOVATION AND SOCIAL \\ ENTREPRENEURSHIP IN THE \\ Hacettepe University Journal of Economics and Administrative Sciences \\ Vol. 37, Issue 1, 2019, pp. 169-187}

\section{FUTURE OF SOCIAL WORK PROFESSION}

\author{
Buğra YILDIRIM \\ Assist.Prof.Dr., Manisa Celal Bayar \\ University \\ Faculty of Health Sciences \\ Department of Social Work \\ bugra.yildirim@cbu.edu.tr

\section{Tarık TUNCAY} \\ Prof.Dr., Hacettepe University \\ Faculty of Economics and Administrative \\ Sciences \\ Department of Social Work \\ ttuncay@hacettepe.edu.tr
}

A small part of this study were presented by writers as an oral presentation with the title of "Social Innovation and Social Entrepreneurship in the Future of Social Work" at the International Social Work Congress held in Ankara on 29-31 May 2017. bstract: Social innovation and social
entrepreneurship have begun to be
referred as two new concepts in social
work terminology. We must go beyond the traditional methods to share new information with those who want to benefit from the theoretical approaches and practices of the profession. The new transformation and practice processes of social workers working with vulnerable groups can be defined as social innovation. The new methods and techniques used by social workers can be defined as social entrepreneurship. This article aims to discuss the role of social innovation and social entrepreneurship in social welfare services and especially in the practice of the social work profession. Social innovation and social entrepreneurship can present different and promising perspectives on scaling social problems. Therefore, social innovation and social entrepreneurship should be encouraged as a series of new strategies developed by social workers for social problems.

Keywords: Social innovation, social entrepreneurship, social work profession, social workers. 


\section{GíRiş}

“Delilik, aynı şeyi tekrar tekrar yapıp farklı sonuçlar beklemektir." Albert Einstein

Sosyal inovasyon ve sosyal girişimcilik, sosyal hizmetin terminolojisinde iki yeni kavramdır. Sosyal inovasyon, sosyal alandaki yenilikçi hizmetlere ve süreçlere vurgu yapan bir şemsiye kavramdır (Popescu, Gheorghe, 2015). Sosyal inovasyon, sosyal ihtiyaçların karşılanması hedefiyle harekete geçirilen ve temel amaçları sosyal sorunları çözmeye çalışan kurumalar aracılığıyla uygulamaya dökülen yeni fikir, faaliyet ve hizmetleri ifade eder (Mulgan vd., 2007: 8). Bir sosyal sorunun önceki çözümlerden daha etkin, daha verimli ve sürdürülebilir çözümü olarak tanımlanabilir (Mulgan vd., 2007; Popescu, Gheorghe, 2015; Makarov vd., 2017).

Sosyal girişimcilik ise sosyal sorunların çözümünde serbest piyasanın rol oynamasıyla ilgilidir. Sosyal inovasyona kurulan bir köprüdür. Sosyal girişimciler, belirli bir örgütsel form çerçevesinde inovatif eğilimlerini uygularken sosyal değişimi hedefler (Nandan vd., 2015). Sosyal girişimciliği, sosyal sorunları çözmeye yönelik çabaları veya örgütlenmeleri geliştirmek için girişimci ilkelerin (risk alma, yenilikçi yaklaşımlar ve sürdürülebilir işletme modelleri $v d$.) kullanılması olarak tanımlayabiliriz (Austin vd., 2006; Mair, Marti, 2006; Nandan vd., 2015).

Bugün sosyal yaşamda deneyimlenen durumların çoğu başlangıçta toplum tarafından radikal veya aykırı yenilikler olarak görülmüştü. Yüzyıllar önce, arabaları sürmek için sıradan insanların güvenilir olabileceğine çok az sayıda kişi inanmıştı. Yüksek hızlı toplu ulaşım araçları, internet, ulusal bir sağlık hizmeti gibi fikirler saçma olarak değerlendirilmişti. Örneğin, başlangıçta bir ütopya olarak dillendirilen anaokulu kavramı eğitimde devrim yarattı. Yukarıda sayılanlar ve burada yer veremediğimiz pek çok farklı sosyal inovasyon örneği marjinal olmaktan çıkıp doğal süreçlere dönüştü. Yakın tarihin bazı dönemlerinde sivil toplum, insanlığa sosyal yenilikler sağladı. Sanayileşme dalgası ve on dokuzuncu yüzyılda hızlanan kentleşme hareketleri, sivil toplumun sosyal inovasyon ve sosyal girişimcilik algısına eşlik etti (Mulgan, 2006).

Sosyal inovasyon ve sosyal girişimcilik, serbest piyasa ekonomisinin toplumsal sistemlerle ve gündelik sosyal yaşantı ile yakınlaşması sonucunda doğdu. Hükümetler ve işletmeler ekonomiyi canlı tutmak, ulusal geliri ve istihdam oranlarını yükseltmek için sosyal inovasyona ve girişimciliğe özel bir ilgi göstermeye başladı. Bu süreçte, sosyal refah hizmetleri yalnızca kamunun yükümlülüğü olmaktan çıkarken, kooperatifler, sendikalar, mikro-krediler ve sosyal sorumluluk projeleri gibi girişimler sosyal inovasyon ve girişimciliğin ilk çıktıları oldu. 
YILDIRIM, TUNCAY $\mid$ The Role of Social Innovation and Social Entrepreneurship in the...

Sosyal inovasyon ve sosyal girişimcilik kavramları, AB ülkelerinde ve Amerika Birleşik Devletleri'nde büyük ilerlemeler kaydetmiştir (Defourny, Nyssens, 2010). Teknoloji, işletme, girişimcilik ve kar amacı gütmeyen pazarlama literatürlerine bir inceleme alanı olarak girmiştir. Ne var ki, çeşitli alanlardan yararlanılarak elde edilen sosyal inovasyon ve sosyal girişimcilik literatürünü gözden geçirdiğimizde, parçalı olduğu ve halen tutarlı bir teorik çerçeveden yoksun bulunduğu görülmektedir. Özellikle sosyal girişimciliğin günümüzdeki açıklamaları; sosyal girişimciliği kullanacak mesleklerin kendilerine özgü nitelikleri ve içinde faaliyet göstermeleri gereken bağlamı yeterince dikkate almamaktadır (Weerawardena, Mort, 2006). Bu mesleklerden biri olan sosyal hizmetin de, sosyal girişimcilik teorisi, sosyal inovasyon, sosyal hizmet yönetim uygulamaları, sosyal hizmet müdahale yöntemleri ve politika yönelimleri üzerinden artık yeni tartışmalara yol alması gerekmektedir.

70'li yılların sonundan itibaren, toplumsal hareketlerin etkisiyle sosyal hizmette sosyal sorunların çözümü ve sosyal değişim için yeni arayışlar ve yeni kulvarlar açma eğilimi oluşmuştur. Bu dönemde Thomas (1978)'a göre sosyal inovasyon ve sosyal girişimcilik ile birlikte sosyal teknoloji, sosyal hizmet mesleğinin hedeflerine ulaşmanın teknik araçları olarak tanımlanmaya başlamıştır. Sosyal hizmette yeni sosyal teknoloji üretmek için sürekli bir ihtiyaç bulunmaktadır ve eski araştırma yöntemleri yeni sosyal teknolojiler geliştirme görevi için uygun değildir, farklı bir metodolojiye ihtiyaç duyulmuştur. Nitekim mesleki güncellemelere duyulan açlık dinamik bir beklenti olarak sosyal hizmet adına karşımıza çıkmıştır.

\section{Mesleki Dönüşüm ve Yenilik İhtiyacı}

Sosyal hizmet mesleğinin kuramsal yaklaşımlarından ve uygulamalarından yararlanacak kişilere ulaştırmak istediği yeni bilgileri paylaşmak için geleneksel yöntemlerin dışına çıkması gerekmektedir. Sosyal çalışmacıların incinebilir gruplarla çalışırken geçirdiği yeni dönüşümü ve uygulama sürecini sosyal inovasyon, kullandığ 1 yeni yöntemleri ise sosyal girişimcilik başlığı altında değerlendirmeliyiz.

Bu noktada özellikle sosyal hizmette sosyal inovasyon kavramının neden yeni bir dönüşüm ve uygulama süreci biçiminde tanımlanması gerektiğini açıklamak zorundayız. Sosyal inovasyonlar, yani toplumsal olarak organize edilen ya da sosyal hizmetlerdeki yeni fenomenler; toplumun değişen sosyal koşulları bağlamında belirli bir gelişim aşamasından geçer. Ayrıca sosyal hizmetlerde sosyal inovasyonlar bireylerin sosyal alanında gerçekleşen etkili olumlu dönüşümleri tetikler. Bu nedenle sosyal çallşmacıların incinebilir gruplarla çalışırken geçirdiği yeni dönüşümü ve uygulama sürecini sosyal inovasyon biçiminde tanımlarız. Sosyal hizmet alanındaki sosyal inovasyon anlayışı sosyolojik, teknolojik ve diğer yeniliklerden farklı birçok özelliğe sahiptir. (Plotinsky, 2012; Cajaiba-Santana, 2014; Makarov vd., 2017). 
Öncelikle sosyal inovasyon daha geniş katılımlı kolektif yaratıcıllğın bir sonucudur. Oysa materyal ve teknolojik inovasyonlar belirli bir grup uzman, ekip, yazar ve birey tarafindan tasarlanmaktadır. Ek olarak, materyal ve teknolojik inovasyonların maddi yönü daha kuvvetli ve geri dönüşü hızlı olduğu için toplumsal etkileri doğrudan veya daha spesifiktir. Sosyal inovasyonların toplumsal etkileri ise geri dönüşü biraz daha geç olabileceği gibi bir sonraki kuşağı ya da jenerasyonu etkileyecektir (Makarov $v d .$, 2017).

Örneğin bugün sosyal hizmet alanında yoksulluğun çözümüne yönelik tartışllan yeni bir uygulamanın yarın yoksulluğa çözüm üretmesini istemek beklentilerimizin çok ötesinde olur. Sosyal hizmetlerde sosyal inovasyonların kabulü ve beklendik toplumsal etkileri bir süreci ister istemez doğuracaktır. Dahası sosyal inovasyonlar dış çevre üzerinde oluşturulmuştur. Sosyal inovasyonların kullanılacağı uygulama alanları, geniş bir sosyal yaşam olgusu çerçevesinde, sosyal uygulamalara dâhil olan kişilerin bireysel özelliklerine ve grup dinamiklerine bağlıdır. Çözümlenememiş sosyal sorunlar ise toplumsal alanda yeni yöntem, araç ve düzenlemelerin geliştirilmesine zemin hazırlamaktadır (Makarov vd., 2017). Bu nedenle sosyal inovasyon kaynakları; dış çevrede meydana gelen değişimleri, geleneksel yöntemlerle çözülemeyecek sosyal sorunları ve toplumun taleplerindeki değişiklikleri içerir (Baker, Mehmood, 2015).

21. yüzyıl sosyal hizmet uygulamasında yeni veya önemli ölçüde değişen bir süreç bizleri bekliyor. Hızlı toplumsal değişim ve dönüşümle ülkelerin sınırları, ihtiyaçları, bireylerin beklentileri değişmekte ve teknolojik devinimle birlikte araçlar, ulaşım ve iletişim kalıpları farklılaşmaktadır. Ne var ki yeni sosyal sorunlara halen eski kavram ve uygulama yaklaşımları ile müdahale edilebilmektedir. Oysa sosyal çalışmacılar mesleki yetkinliklerini toplumda müracaatçılarından aldıkları için yeni kavramlarla ve araçlarla bireylerin psikososyal ve ekonomik sorunlarına yeni ve etkili yanitlar üretmelidirler (Atkins, Frederico, 2017) .

Sosyal çalışmacılar güncel kavramsal çerçeveleri ve uygulama yöntemlerini kullanmak için gerekli çabayı göstererek müracaatçı sistemine etkili müdahaleler yapabilirler. Toplumsal sistem dinamiktir ve ihtiyaçlar ile bunları karşılayacak araçların değişmemesi söz konusu olamaz. Duyan (2010: 2)'a göre 'toplumlar arasında bazı farkl11ıklar olmakla birlikte meydana gelen değişikliklerden doğrudan ya da dolaylı olarak etkilenmeyen bir grubun olması söz konusu değildir'. Dolayısıyla toplumsal yapıda meydana gelen değişimler tek bir ülkeye, gruba, mesleğe özgü de değildir. Değişen dünyada sosyal inovasyon ve sosyal girişimcilik kendilerine özgü nitelikleri ile sosyal hizmetin geleceğinde önemli bir konuma sahip olacaktır. 


\section{Sosyal Hizmet Sunumunda Benimsemesi Gereken Farklı Kuramsal Yaklaşımlar}

Sosyal inovasyonun ve sosyal girişimciliğin başarısı -sosyal yeniliklerin girişimcilik yoluyla uygulanması- birçok faktöre bağlıdır. Öncelikle, gündelik yaşamın sosyal alanında sosyal çalışmacılar çok yetkin olmak zorundadır. Onlar, sosyal inovasyonların uygulanması konusunda bilimsel bilgiye sahip olmalı ve pratik girişimci becerilere sahip olmalıdır. İlaveten, büyük ölçekli inovasyonların uygulanması, yasal, sosyoekonomik ve organizasyonel konuların dikkatli bir şekilde ele alınmasını gerektirmektedir (Makarov vd., 2017). Nitekim sosyal inovasyon konusuyla ilgili girişimleri yönlendiren bakış açılarını ve sınıflandırmaları hatırlatmakta gereklidir.

Bugüne kadar sosyal inovasyon konusuyla ilgili girişimleri iki kuramsal bakış açısı yönlendirmiştir. Bir tarafta sosyal inovasyonun belirli bireyler tarafından üstlenilen eylemler aracılı̆̆ıla yaratıldığı bireyci ve davranışçı bir yaklaşım olan temsil merkezli bakış açısı vardır. Diğer tarafta, sosyal inovasyonun dışsal yapısal bağlam tarafından şekillendirildiği yapısalcı bakış açısı bulunur. İlkinde bireysel inovasyon değerleri ve nitelikleri, sosyal inovasyonu belirlemede nedensel güçtür. Bu bakış açısı tüm inovasyon firsatlarının önemli olduğunu kabul eder ancak sosyal yapıların ve kurumların rolüne daha az dikkat çeker. İkincisi, sosyal inovasyon çalışmaları alanında en çok ilgi görendir. Toplumsal yapının ve sosyal bağlamın inovasyon için nedensellik faktörü olacağını ima eder. Toplumun sosyal alanında; yeniliklere duyduğu ihtiyacın, yeniliklere uyum kapasitesinin, ekonomik coğrafyasının, karşılaşığı yeni fikirlere olan tutumunun analiz edilerek inovasyon sürecine başlanmasını savunur (Cajaiba-Santana, 2014).

Ayrıca sosyal inovasyonları, seviyesi ve kapsamı açısından ortak insani sorunların çözümüne odaklanan küresel, bölgesel ve yerel yenilikler olarak birbirinden ayırırız (Voorberg $v d$., 2015). Sosyal inovasyonları sosyal yaşam açısından; sosyal, politik ve ekonomik yenilikler, kültürel ve manevi alandaki yenilikler, sosyal yapı ve kurumlardaki yenilikler olarak birbirinden ayırırız (Manzini, 2014; Popescu, Gheorghe, 2015). Sosyal inovasyonları toplumsal alanın yapısı açısından; eğitim, yönetim, istihdam, emeklilik, spor gibi pedagojik, eğitsel, yasal, yönetsel ve sosyal yenilikler şeklinde birbirinden ayırırız (Martin, Upham, 2016).

Sosyal inovasyonları toplumsal alanın yapısı açısından ele aldığımız zaman sosyal girişimciliğin toplumsal kalkınmada oynayabileceği rolü de saptamamız gerekir. Sosyal bir amaçla kurulan sosyal girişimler, ekonomik faaliyetler yürütür ve elde ettikleri kârı sosyal amaçlar için kullanır. Sosyal girişimler, çoğunlukla ürün ve hizmetler yaratırken incinebilir grupları istihdam eder. Sorun ve firsatları fark eder. Doğru değerlendirme, risk alma gibi girişimcilik odaklı bir yaklaşım izler. Sosyal 
girişimlerin farkındalık yarattığı nokta; etkili uygulamalar ve sosyal hizmetler sağlayarak kamunun üzerinden yük almasıdır (Ersen, Ekmekçi, 2018).

İstihdam imkânları yaratan sosyal girişimler, ayrıca birer piyasa aktörü olarak ekonomik büyümeye de katkıda bulunur. Sosyal girişimcilik projeleri, toplumda kadınlar, azınlıklar, engelliler gibi incinebilir konumda bulunan grupların istihdamını sağlayarak bu grupların toplumla bütünleşmelerine yardımcı olur. Kısacası sosyal inovasyon ve sosyal girişimcilik ülkelerin kalkınmasına katkıda bulunarak olumlu sosyal değişimi tetikler. Sosyal inovasyon ve girişimciliği farklı kılan özelliklerden bir başkası da sosyal sorunlara bütünsel ve sistematik çözümler aramasıdır. Sosyal inovasyon ve girişimcilik; yarattığı çözümlerle beraber başka bölgelerde yeniden uygulamaya dökülür ve sosyal sorunların çözümü için yeni yollar arar (Ersen, Ekmekçi, 2018). Ancak başka bölgelerde sosyal inovasyonlar ve sosyal girişimcilik uygulamalarını ele alırken sosyal inovasyonun kültürle ilgili boyutunu göz önünde bulundurmamı gerekir.

\section{Sosyal İnovasyonun Kültürel Boyutu}

Sosyal hizmetlerde sosyal inovasyon süreci, belirli bir faaliyet alanında elde edilen yeni bir deneyimdir. Öte yandan, yeni bir deneyimin sosyal sorunlara karşı uygulamaya dökülmüş hali ve kültürün temsilidir (Makarov vd., 2017). Kültürün ulusların yenilikçilik ve girişimcilik performansları üzerindeki etkilerini karşılaştırmalı olarak incelemek için her kültürde az ya da çok oranda ortak olan bazı olguların bulunduğu varsayılmalıdır (Hofstede, 2001: 24). Her kültürde sosyal sorunların çözümüne karşı harekete geçme ve değişimi sağlama isteği ortak olan olgulardandır.

Kültürel değerlerin büyük bir kısmı o ülkede faaliyet gösteren örgütlere ve şirketlere yansıyabileceği (Minkov, Hofstede, 2011) gibi sosyal hizmet alanında da etkilerini gösterir. Toplumsal değerler haricinde bir kısım değerler ise o örgütün kendine has alt kültürlerini oluşturmakla beraber yoğun biçimde söz konusu örgüt, içinde bulunduğu toplumdan etkilenmektedir (Hofstede, 2011; Minkov, Hofstede, 2011). Bu yüzden çeşitli ülkelerde aynı örgüte bağlı olan yapılarda/şubelerde/distribütörlerde kültür farklılığı nedeniyle birbirinden farklı gelişim ve davranış örüntüleri sergilenmektedir.

Aynı bakış açısı kültür farklılığı nedeniyle her ülkede sosyal hizmet sunumunun çeşitlenmesine de neden olmaktadır. Bir ülke için sosyal sorun olarak nitelen konular bir başka ülke için sosyal sorun olarak değerlendirilemeyebilir. Bu görüşün aksine, günümüzde başka bir ülkenin sosyal sorunu kendi sınırlarını aşabilmekte ve farklı bir ülkenin sosyal sorununa dönüşebilmektedir. Ancak farklı bir ülkenin sosyal sorununa dönüşen durum ise o yeni ülke içinde kültürel farklılıklardan dolayı ayrı ayrı yönlerden 
ele alınmaktadır. Türkiye için en iyi örnek Suriye İç Savaşı ile ülkemize göç eden sığınmacılar hakkında verilebilir. Suriye toplumunda göç, can güvenliği, iç savaş gibi sosyal sorunlar tartışlırken Türkiye'de Suriyelilerin toplumsal kabulü, uyumu ve yerleşimi ile ilgili sorunlar önceliklidir.

Pek çok açıdan sosyal inovasyonun ve sosyal girişimciliğin nasıl yapıldığı ve yayıldığı noktasında büyük bir değişim sürecinin parçası olduğumuz unutulmamalıdır. Sadece bilim, yatırım, donanım, teknoloji, elimizdeki akıllı telefonlar, altımızdaki araçlar değil sosyal inovasyonun ve girişimciliğin artık toplumsal hizmetlerle de ilgili olduğunu anlamak zorundayız. Kamu sektöründe inovasyon ve girişimcilik, kullanıcı odaklı inovasyon ve girişimcilik, sanayide inovasyon ve girişimcilik, tarımsal inovasyon ve girişimcilik, sosyal hizmetlerde inovasyon ve girişimcilik gibi başlıklar toplumsal hizmetlerle ilgilidir. Bu yönüyle sosyal inovasyon ve sosyal girişimcilik sosyal hizmet alanında fark yaratacak kavramlar arasında gözükmektedir.

\section{İletişim Devrimi}

Konunun bir de teknoloji tarafi, daha özel olarak 'iletişim devrimi' kısmı vardır. İletişim devrimi, fiziksel teknolojiye, öğrenmeye ve sosyal bağlantıların etkileşimine dayalı olarak bugün toplumsal ilişkileri açıklar hale gelmiştir. Örneğin Türkiye'de 'ekşi sözlük' ve 'wikipedia' yazarlığı, 'facebook, twitter ve instagram' gibi sosyal medya araçlarının kullanımı kişilerin içinde yer aldığı sosyal ağlar ile değerlendirilmesine etki etmektedir. Dolayısıyla kişilerin sosyal destek kaynaklarına fiziksel sosyal çevrenin yanı sıra sanal bir sosyal çevre de eklenmiştir. İletişim ortamı da zemin değiştirmektedir. Devlet başkanları, siyasetçiler, bürokratlar, kanaat önderleri vb. birçok kişi ve kurum daha geniş insan yığınlarına ulaşabilmek için sosyal medyayı yoğun biçimde kullanmaktadır. Ülkeler bu yolla birbirlerini eleştirmekte ya da birbirlerinden haber almaktadır.

Dünya sürekli değişmekte ve sosyal çalışmacıların mesleki olarak odaklandıkları sosyal alan adeta 'mutasyon'a uğramaktadır. Flynn (2017) insanlar arasındaki diyaloglarda yüz yüze karşılaşmaların elbette temel olmaya devam ettiğini söylese de insan tecrübesine bağlı iletişim boyutlarının farklı, daha çeşitli ve sanal ortamda halen tam olarak anlaşılmayan bazı kurallarla sürdüğünü ifade etmektedir. Sosyal hizmet disiplini; sinirbilim, psikiyatri, feminizm gibi akımlardan etkilenmeye devam ediyor olsa da, mesleğimizin değişim hedefiyle ilgili temel araçlarını düşündüğümüzde, yenilikçi yaklaşım ve girişimler özellikle iletişim alanında değerini yükseltmektedir. 


\section{Kamu, Sivil Toplum ve Özel Sektör Üçgeninde Sosyal Hizmetlerin Sunumu Meselesi}

Sosyal refah sisteminin 'liberalize' olduğu, girişimci bir 'eko-sosyal' sistemde sosyal hizmet mesleğinin konumunu yalnızca kamu hizmeti veya sivil toplum tarafinda koruması artık beklenmiyor. Sürekli bir 'ortak sorumluluk' vurgusu yapılıyor (Akbaş ve Tuncay 2005). Bugün hem kamu, hem sivil toplum hem de eskiden olmadığı kadar yoğun olarak özel sektör sosyal hizmetlerin sunumuyla ilgilidir. 21.yüzyılda sosyal hizmetin konumunun özel ve bireysel girişimlerle desteklenmesi gerektiği daha çok savunulur hale de gelmiştir. Çünkü mesleğin, değiş̧ken müracaatçı gereksinimlerine bilindik şablonların ötesinde dinamik yanıtlar üretmek zorunda olduğu düşünülmektedir. Örneğin Halvorsen (2016) sosyal hizmet araştırmacılarının toplumsal ihtiyaçlara en iyi yanıtı verebilmek için genellikle 'yavaş ve (fazla) metodolojik bilimsel araştırma topluluğu' ile 'hızlı ve reaktif sosyal yenilik topluluğu' arasında denge kurduğunu savunur.

21. yüzyılın ekonomik, politik ve sosyal gerçekleri göz önüne alındığında sosyal hizmet bir yandan kurduğu dengeyi sürdürme öte yandan da ekolojik sistem, güçlendirme, çevresi-içinde-birey gibi temel yaklaşımların zihinsel malzemelerine ek olarak yeni kavramlara ulaşma ihtiyacı göstermektedir. Bu nedenle sosyal hizmetin geleceğinde nerede ve ne ağırlıkta yer alacağı merak konusu olan sosyal inovasyon ve sosyal girişimciliğin gözden geçirilmesi gerekmektedir. Bu makalenin amacı, sosyal inovasyon ve sosyal girişimciliğin genelde sosyal refah hizmetlerinde özelde ise sosyal hizmet mesleğinde oynayacağı rolü tartışmaya açmaktır.

\section{SOSYAL HİZMETE ETKİLER}

Sosyal bağlamda savunmasız olan nüfusu etkileyen sosyal sorunları çözmek için sosyal hizmet, inovasyon ve girişimcilik ilişkisi umut vaat eden bir ortaklık olarak çeşitli firsatlar taşıyor (Bahar, 2017). Bu ilişki kervanına bilim de eklendiği zaman bilimi ve sosyal inovasyon perspektifini aynı akademik çatı altında birleştirmenin bir sonucu; yeni toplumsal yapılandırmaların, organizasyonların, bilimsel yöntem ve kavramların tekrar değerlendirilerek yeni formüller ile filizlenmesi olmaktadır (Flynn, 2017).

Kamu sektöründeki değişim örgütlerin klasik çalışma mekanizmalarını değiştirdi. Çoğu örgütün ve hatta ülkelerin yatırımlarında ciddi kısıtlamalar olmasına rağmen -zaten kısıtlı olan- sosyal hizmet alanı bu kısitlamalardan daha az etkilenmekte, standartları yükseltmeye ve uygulamada iyileştirme yapmaya ihtiyaç duymaktadır. Bu bağlamda sosyal inovasyon ve sosyal girişimcilik örgütsel ve bireysel algıyı yükseltmek adına yatırım yapılması gereken yeni süreçler olmuştur. Sosyal hizmet alanlarında bir 
fikri üretme aşamasından sosyal sorunların çözümlenmesine yönelik her adımda yenilikçi yaklaşımlar kullanmak, daha istekli olmak, sistemin dönüşümüne her aşamada katkıda bulunmak ve farklı disiplinlerden yeni kavramlar devşirmek mesleğin bilgi gövdesine katkıda bulunur. Elde edilen yeni bilgi üretimi paylaştıkça ve topluma yayıldıkça kıymetlenir. Bu noktada iki kavram daha karşımıza çıkmaktadır: 'Kanıta dayalı uygulama' ve 'risk yönetimi'. Sosyal inovasyon ve girişimciliğin kabul edilme düzeyini bu kavramlar daha çok artırmaktadır. Sosyal hizmet uygulayıcılarının ve akademisyenlerin sosyal hizmette ne kadar yenilikçi olduğunun, ne tür yeni fikirlere ve kavramlara açık olduklarının, toplum yararına bu yeni fikir ve kavramları nasıl kullandıklarının, müracaatçıları bu sürece katıp katmadıklarının ve görüşlerini kimlerle paylaştıklarının anlaşılması uygulama sürecinde elde edilen firsatların yayılmasını kolaylaştırmaktadır. Bunların hepsi aynı zamanda sosyal hizmetin yeni araştırma konularıdır.

\section{Sosyal Sorunların Çözümünde Sosyal İnovasyon ve Sosyal Girişimcilik}

Sosyal hizmet mesleği ilgilendiği sosyal sorunlara yeni ve yaratıcı çözümler üretmeye çalışarak sosyal inovasyon ve sosyal girişimciliği genişletir. Sosyal hizmetlerde yenilikçiliğin ilerletilmesi, karmaşık ve sürekli değişen bir sistemde kararlar alınması anlamına gelecektir. Sistem dinamikleri gibi karmaşıklığı hesaba katan yöntemlerden alınan ilkeler ve araçlar karar verme sürecinde iyileştirmeye yardımcı olur (Stringfellow, 2017).

Okpych (2017) sosyal hizmette bir yenilik hareketi doğduğunda ilk görevin sosyal inovasyonun nerede ve nasıl yer alacağını simgeleyen modeller geliştirmek ve denemek olduğunu belirtir. Sosyal inovasyon ve girişimciliğin yer alacağı modeller sosyal sorunların çözümüne yönelik yeni seçenekler yaratan işlevsel düzenlemeler ve ortaklıklardır. Düşünce kuruluşları, üniversiteler, kamudaki sosyal hizmet kurum ve kuruluşları, sivil toplum örgütleri, sosyal proje koordinasyon merkezleri vb. taraflar yenilikçi ve girişimci işlevsel düzenleme ve ortaklıkların aslında bütün paydaşlarıdır. Tüm bu paydaşların sosyal hizmet uygulamalarında neden sosyal inovasyon ve girişimciliğge ihtiyaç duyduklarını açıklamakta yarar vardır.

\section{SOSYAL INOVASYONUN VE SOSYAL GIRIŞiMCILIIĞIN GENIŞLEYEN KAPSAMI}

Sosyal girişimcilik, son otuz yıl içinde aktif bir uygulama ve araştırma alanı olarak ortaya çıkmıştır. Yine de, giderek artan popülaritesine rağmen, akademisyenler ve uygulayıcılar, sosyal girişimciliğin aslında ne anlama geldiği konusunda bir fikir birliğine varmaktan uzaktırlar. Bu durum, sosyal girişimciliğin birtakım farklı tanım ve yaklaşımlar ele alınarak anılması ile sonuçlanmıştır (Choi , Majumdar, 2014). Aslında 
sosyal inovasyon ve sosyal girişimciliğin bütün taraflar arasında kabul edilecek evrensel bir tanımını yapmak da mümkün değildir. Makalenin yazarları, tartışmalı doğasına rağmen sosyal inovasyon ve sosyal girişimciliği tutarlı bir araştırma alanı olarak sosyal hizmet literatürüne ilave edilebilecek kavramsal bir araç olarak görmektedirler.

İnovasyon ve girişimcilik kelimeleri içeriklerinde olumlu ve olumsuz yanları barındırabilirler. Olumlu yanlar özel bir işi hissetmek, doğal bir yeteneği gelişstirmek, her firsatta hareket etmek, olumsuz durumlara çözüm üretmek, bir şeyler yaratmak, uyarlamak vb. olabileceği gibi olumsuz çağrışımları da kar amacı gütme, ekonomik fayda sağlama, teknoloji ve pazarlama başlıkları altında tanımlanma, gerçek etkilerini görmeden önce zamana bırakma vb. olabilir. Bu kavramların başına sosyal kelimesi geldiği zaman biraz anlamlarını biraz da amaçlarını değiştiriyor. Böylelikle sosyal inovasyon ve sosyal girişimciliğin sosyal hizmetin geleceğinde oynayacağı rol de ortaya çıkmış oluyor. Öncelikle sosyal girişimciliğin, toplumsal değişimi körükleyen ve önemli sosyal ihtiyaçları girişimcilere ve uygulayıcılara doğrudan mali yararlar kazandırmayacak şekilde ele alan bir süreç olarak karşımıza çıktığını söyleyebiliriz (Mair, Marti, 2006). Sosyal girişimcilik, toplumsal değeri ve gelişimin ön planda olduğu ekonomik fayda sağlamanın teşvik edilmesine verilen önemin ise nispeten daha düşük öncelikte olduğu ve bu yönüyle de diğer girişimcilik türlerinden ayrılan bir kavramdır.

\section{Sosyal Hizmet Neden Sosyal İnovasyon ve Girişimciliğe İhtiyaç Duyar?}

Sosyal hizmet mesleği, sosyal inovasyon ve girişimcilik benzeri angajmanlarla şu şekilde etkileşime geçebilir: Mesleğin gelişmesi ile birlikte sosyal hizmet araştırması ve uygulama alanı sürekli genişlemektedir. Örneğin, Dünya'da pek çok sosyal hizmet araştırmacısı bugün HIV/AIDS'in psikososyal yönlerini incelemektedir. Benzer şekilde insan kaçakçılığı, göç, kentleşme, yoksul ülkelerin gıda güvencesizliği, adli sistemdeki sorunlar ile çevresel sorunlar ve yeşil sosyal hizmet, azınlık istihdamı, barınma, sağlık, teknoloji ve medya bağımlılı̆̆ gibi konular da bireyler üzerinde yaratılan olumsuz fiziksel ve psikolojik etkilere yaratıcı yöntemler doğrultusunda müdahale etme ve araştırma yapma ihtiyacı oluşturur (Özmete, Akgül Gök, 2015; Bahar, 2017). Çocuk koruma hizmetleri, engelli ve yaşlı bakım kuruluşları, toplum sağlığı merkezleri ve hastane uygulamaları sosyal çalışmacıların özel bir nüfus grubu ve yöntemde uzmanlaştığı, müracaatçılarının ihtiyaçlarını ele alabildiği ilkeler üzerine kuruludur. Özel bir nüfus grubunun ihtiyaçlarını samimi bir şekilde bilmek suretiyle daha az kaynak kullanıp daha çok çalışarak sosyal inovasyon ve girişimcilik rolleri sayesinde daha çok mesafe kat edilebilir (Traube $v d .$, 2017).

Sosyal inovasyon ve sosyal girişimciliğe sosyal hizmetin ilgisinin artmasında pek çok faktörün etkisi vardır. Sosyal hizmet tarihi, araştırmaları, uygulamaları ve eğitimi belirli noktalarda eksik kalabilmekte; güncel sorunlara yeni yaklaşımlar 
sunamamaktadır. Eğitim, araştırma ve uygulama noktasında çoğu sosyal hizmet okulunda egemen olan 'mikro' anlayış sosyal hizmet mesleğinin diğer yönleri üzerinde baskın bir önceliğe sahiptir. Dolayısıyla savunuculuk, topluluk örgütlenmesi ve sosyal adalet hareketi gibi sosyal çalışmacıların daha aktivist yönelimleri ve bu alanlarda değişimi nasıl sağlayacaklarına yönelik düşünceleri hala görece arka plandadır. Pek tabi ki bu durağanlık akademik ve mesleki çevrenin yönetimsel tutumlara ve diş finansmanlara olan bağımlılıklarının artması ve finansman organlarının öncelikleri de dâhil olmak üzere sayısız bağlamsal faktörle açıklanabilir. Sosyal hizmet okulları mikro ve makro düzey müdahaleler arasındaki boşluğu doldurmak için de mücadele etmelidir (Bahar, 2017). Bu boşluğu doldurmada sosyal inovasyonun ve girişimciliğin anlamlı etkileri olabilir.

Rodriguez $v d$. (2017) modern sosyal hizmetin karşı karşıya olduğu temel meseleyi, toplumsal sorunlar ve onların çözümlerine bireysel düzeyde müdahalelerin ötesine geçememe ve adeta 'suskun kalma' olarak ifade eder. Sosyal hizmette sosyal inovasyon süreci, yeni bir fikir oluşturma, geliştirme, kullanma, ürün tasarlama ve sosyal hizmetler adına bilimsel bilgi ve pratik deneyimleri kullanmayı amaçlayan etkinlikleri içerir. İnovasyon süreci toplumsal değişimin özünü yansıtır. Toplumsal değişim ve gelişimin kaynağını şekillendirir. Sosyal sorunlara yönelik hali hazırda var olan bakış açılarını kaçınılmaz bir biçimde dönüştürür (Makarov vd., 2017). Sosyal girişimcilik algısı sayesinde de ortaya çıkan yenilikler ve değişen bakış açıları sosyal hizmet adına mikro, mezzo, makro düzey uygulamalar ile topluma sunulur. O zaman mikro, mezzo ve makro düzey bilgi akışlarını bir araya getirmeye yönelik süreçler tekrar geliştirilmelidir.

\section{Sosyal Sorunları Ölçeklendirmeye Katkı}

Sosyal inovasyon ve sosyal girişimcilik sosyal sorunları ölçeklendirmede farklı bakış açıları sunabilir. Sosyal hizmet uygulama ve araştırma bilgileri farklı bakış açıları ile zor sosyal sorunlardan etkilenmeyecek şekilde müracaatçılara alternatif hizmet sunabilir. Mesleğin uygulama boyutunu çözüm odaklı bir üst perdeye taşımak için üç somut strateji ortaya konmuştur (Rodriguez vd., 2017):

1- Sosyal hizmet bilgisinin mesleğin üç büyük araştırma ve uygulama alanıyla (mikro-mezzo-makro düzeylere) daha fazla bütünleştirilmesi,

2- Sosyal hizmet eğitimi ve araştırmasında politika analizlerinin yoğunluğunun arttırılmas1, 
3- Sosyal pazarlama, sosyal medya, politik savunuculuk ve yenilikçi, girişimci bir ruh ile kamuoyunda sosyal hizmet sorun tanımları ve çözümlerinin görünür kılınmasını sağlamaktır.

Elimizde üç somut strateji bulunurken bile durum ne yazık ki böyle değildir. Sosyal hizmet uygulamalarına yönelik yaygın politika geliştirme sürecinde mevzuatla ilgili tartı̧̧ma ve beyanlar karşısında suskun kalmaktayız. İlke olarak sosyal hizmet sektöründeki sorunların sosyal hizmet alanı içinde çözülme eğilimini savunsak da uygulamada sosyal hizmet sektörüne yönelik halen bürokratik bakanlıklar etrafinda organize olmaktayız (Traube $v d ., 2017$ ).

Flynn (2017) sosyal inovasyon ile girişimciliğe sosyal hizmet kurumlarında ve sosyal hizmet sunum alanlarında yer açmak gerektiğini savunur. Çünkü bir taraftan sosyal hizmet ise değerleri, sosyal amaçları ve bağlama özgü uygulamalarıyla bu alanların gelişmesine katkı verme potansiyeline sahiptir. Sosyal hizmet, dünyadaki karmaşık sorunlara yenilikçi çözümler üretme konusunda da yalnız değildir. Sorunlara yenilikçi çözümler geliştirmek için disiplinlerarası ekipler, topluluklar ve uygulayıcılarla ortaklıklar kurulmaktadır (Stringfellow, 2017). Meslek olarak diğer disiplinlerin egemenliği altındaki sosyal sorunları da kapsayacak şekilde sosyal hizmet tanımının güncellenmesi ve genişletilmesi sosyal inovasyon ve girişimciliğin en güzel örneklerindendir. Karma yöntemin sosyal hizmet araştırmalarına yansıması ya da Türkiye'de mesleğin adı hakkında akademik çevrelerce bilimsel tartışmaların yaşanması, sosyal yardım bilgi sistemine (SOYBİS) geçiş ve ortaya konabilecek pek çok başka gösterge sosyal inovasyon ile sosyal girişimciliğe aslında ne kadar muhtaç olduğumuzu göstermektedir.

\section{SOSYAL INOVASYON, SOSYAL GIRIȘIMCILIK VE TEKNOLOJININ SOSYAL BOYUTU}

Geçmiş yıllarda sosyal hizmetler alanındaki girişimciler, uygulayıcılar, sistemler, kurumlar ve sektörler arası ortaklıklar sosyal inovasyon ve sosyal girişimciliğe özel bir odaklanma göstermişlerdir (Phillips $v d$., 2015). Türkiye'de yapılan bir alan araştırmasında (Özdemir, Ar, 2015) sosyal inovasyonun en fazla ilişkili olduğu kavramın sosyal girişimcilik olduğu, sosyal inovasyonun ortaya çıkışında en önemli faktörün ise sosyal beklentiler olduğu belirlenmiştir. Sosyal inovasyonun en fazla ilişkili olduğu kavramın sosyal girişimcilik olarak belirlenmesi, bu konudaki insan kaynağının önemine işaret eden bir bulgu olarak değerlendirilmektedir. Buna göre sosyal girişimciliğin nitelik ve nicelik açısından geliştirilmesine odaklanılması durumunda yeni sosyal yeniliklerin ortaya çıkması sağlanacaktır (Özdemir, Ar, 2015). 
YILDIRIM, TUNCAY $\mid$ The Role of Social Innovation and Social Entrepreneurship in the...

Sosyal girişimciliğin kar amacı gütmemesi gerektiğini vurgularken inovasyonun hızlı, reaktif ve devrimci olabileceği, kimi zaman nedenselliği basitleştirebileceği ve bilgi kaynağına bakmadan hareket edebileceği göz ardı edilmemelidir. Ancak yeniliğe kalıcı bir ilginin de olacağı bilinmelidir. Toplumsal gelişmeye giden yol yeni ve dinamiktir. Yeni ve farklı girişimlerle şekillenir. Yanıt isteyen çok sayıda sosyal sorunla birlikte yapabileceğimiz çok fazla uygulama (Halvorsen, 2016), üretebileceğimiz yeni kavramlar ve etki edebileceğimiz farklı ortamlar mevcuttur. Başka bir deyişle, mümkün olan en iyi araştırma yöntemleri üzerinde hız ve pragmatizmi tercih etmek için, uygun olduğunda, odağımızı değiştirmeyi göze almamız ya da toplum yararına sosyal hizmet araştırma ve uygulamaları yaparken kullanılan finansman miktarına, yapılan yayınlara ve öğrenilen yeni durumlara ek olarak elde ettiğgimiz çıktıları kolaylıkla kamuya ve etkilenen diğer paydaşlara nasıl ulaştıracağımıza karar vermemiz gerekir. Bunu yaparken sosyal inovasyon ve sosyal girişimciliğe özgü yeni rol ve beceriler geliştirme sorumluluğu sosyal çalışmacıları beklemektedir. Mesleki önceliklerimizi dikkate alıp titiz bilimsel çabaları ve yetkin mesleki uygulamaları dengeleyerek toplumsal etkiyi doğru bir şekilde nasıl ödüllendirebileceğimizi bulmamız önemlidir. Önceliklerimizi gözden geçirdiğimizde bilgiyi topluma yayma, geri dönüş alma ve yeni süreçleri keşfetme zamanımızın geldiğini anlamış oluyoruz.

Bazı sosyal çalışmacılar, toplum organizasyonu, toplum planlaması, sosyal kalkınma ve politika uygulama gibi müdahale stratejilerini 'sürdürülebilir toplumsal değişiklikler' oluşturmak için kullanmaktadırlar. Dolayısıyla farkında olmadan zaten sosyal girişimcilik ruhunu taşıyarak hareket etmektedirler (Nandan $v d$., 2014). Sosyal girişimcilik, toplumsal yeniliklerin uygulanmasına yönelik yaklaşımların kâr amacı gütmeyen sektörlerde, kamusal ve özel alanda sosyal değer yaratmak için müracaatçıların hizmetine sunulması (Schmitz, Scheuerle, 2012; Nandan vd., 2015) iken yenilik sürecinde sosyal çalı̧̧macılar kurumsal ve toplumsal değişim için toplumun katalizörleridir (Zadek, Thake, 1997). Bu nedenle sosyal hizmetler, sosyal sorunlara etkili yanıtlar veren kurumlar ve organizasyonlarla yeni ilişkilerin tasarlanıp sosyal açıdan farklı fikirlerin sürdürülebildiği dinamik modeller olmalıdır. Tam da bu hususta bu tartışma metninin ortaya attığı kavramların söz konusu ana amaca hizmet edeceği ümit edilmektedir.

Öte yandan yeni sosyal sorunlar dizisinin ortaya çıkması teknoloji ile kolaylıkla ulaşabileceğimiz bilgi bağlantımızın artmasına neden olmaktadır. Bu nedenle çözmek için çabaladığımız konuların karmaşıklığı daha fazla iletişim ve işbirliği gerektirir. Özellikle internet kullanımı mesleki sorun çözme süreçlerinde yeni nesil sosyal çalışmacılar tarafından daha popüler ve yaygın bir başvurucu aracı olmuştur. Dahası, teknoloji meraklısı yeni nesiller sosyal hizmette geleneksel yöntemlerin uygulanmasına da meydan okur hale gelmiştir. Bütün bu gelişmeler birleştirildiğinde sosyal hizmet araştırma ve uygulaması yenilikçi düşünmeyi, farklı konuları araştırmayı ve yeni 
yöntemler kullanmayı artık teşvik etmektedir (Bahar, 2017). Sosyal inovasyon ve girişimciliğin ilk önce Avrupa'da kamu finansmanı ve hayırseverliğe alternatif olarak incelenmesine rağmen sosyal hizmetin geleceğinde kendine yer bulacağı düşünülen bu kavramlara ABD'den bir örnek ile açıklık getirmek dikkat çekici olacaktır.

Müracaatçılarımızın yaşadı̆̆g psikososyal ve ekonomik sorunların karmaşıklığı sürekli artmaktadır. Bu zorluklar, sosyal çallşmactların topluluklar ve insanlar üzerinde kalıcı bir etkiye sahip olabilecek sosyal değişime liderlik etmelerini daha çok gerekli kllmaktadır (Nandan vd., 2015). Germak (2017)'a göre sosyal hizmet özelinde liderlik temelli sosyal inovasyon ve sosyal girişimciliğe en çarpıcı örnek Apple'ın kurucusu ve CEO'su Steve Jobs'un hayatından kesit alınarak verilebilir, çünkü o tüm çalışma yaşamını, insanların teknoloji kullanımı yoluyla kendi hayatlarını yönetme biçimlerini değiş̧tirmeye adamıştır. Bir an için, Jobs'un teknoloji girişsimcisi yerine sosyal çalışmacı olduğunu ve dünyanın nasll değişebileceğini düşünelim. Yüz milyonlarca insan artık ihtiyaç duyduğu sosyal hizmetlere rahatllkla erişebilir mi? Sosyal hizmetler, iPhone kadar her yerde yaygın olabilir ve rahatlkkla bulunabilir mi? Jobs'un yenilikçi ve girişimci yolunu takip etmek için daha fazla sosyal çalışmacının olması durumunda neler olacağını düşünmek ilginçtir fakat bunu sağlayabilmek için, sosyal çalışmacılar olarak iş yapma biçimimizi değiş̧tirmemiz de gerekir.

Germark (2017), kişinin başarısı için kararlı bir vizyona sahip olmasının esas olduğunu vurgular. Jobs ona göre, sorunların çözümüne yönelik tüm faaliyetlerimizi nasll yönlendirebileceğimizin teknoloji ayağını düşündü ve daha sonra dünyayı nasıl değiş̧tirmek istediği konusunda çok net bir vizyon geliştirdi. Bu vizyon kariyeri boyunca tutarlı oldu. Tipk Jobs gibi sosyal çalışmacılar da uygulamalarını sosyal etkiyi yönlendirecek düzeyde genel bir vizyona adamalıdir. Böylesi bir vizyon dlş dünyaya açı olduğunda belirli sosyal sorunları çözme kapasitemizi arttırmamıza ve alanımıza yardımcl olur. İkinci olarak inovasyon konusu Steve Jobs'un kariyerine damga vurmuştur. Kendisi yeni ürünleri, tasarmlar ve hizmetleri keşfetmeyi asla bırakmamıştır. Aslında, insanların ihtiyaç duyduklarını veya istediklerini bile bilmedikleri ürün ve hizmetler yaratmaya devam etmiştir.

$\mathrm{Bu}$ anlayışı ile Steve Jobs tam bir girişimcidir. Yaratıcıdır. Fikirlerinin peşinden gitmiş̧ir. Fırsatları görmüştür. Yenilikçidir. Risk almıştır. Tam olarak girişimci özellikleri taşımakla birlikte sadece bu yönü ile sosyal girişimci değildir. Üretip sattığ1 ürünler ile insanların yaşamına kolaylık ve iyilik katmıştır. Kar amacı gütmeden satılan her iPhone'dan elde edilen gelirin bir kısmını, ihtiyaç sahiplerine aktarma yaklaşımına sahiptir. $\mathrm{Bu}$ özelliği onun sosyal girişimci olduğunu kanttlar. Üretilen teknolojik inovatif bir ürünle insanların yaşamına katkı sağlaması yenilikçilik olmakla beraber, sosyal inovasyon bu yeniliğin bir kurum, tüzel kişi tarafından sosyal sorunu çözmek için kullanılmasi ile sosyal inovasyondur. 
Steve Jobs gibi, sosyal çalışmacılar da doğası gereği kısıtlı kaynaklar kapsamında hizmetler sunmak için yaratıcı yollar bulur. Burada önemli olan, 'bir tık daha fazlasını düşünüp' statükoyu bozan ve hizmet sunumunu daha etkin ve verimli hale getiren sosyal hizmetler sunumu sağlamanın yeni yollarını yaratmak için çabalamamızdır. Bir 'sosyal endüstri' olarak sosyal hizmet, teknoloji endüstrisi kadar yenilikçi ve yaratıcı olmalıdır. Sosyal çalışmacılar da yenilikçi ve girişimci roller üstlenmelidir. Girişimcilik sosyal çalışmacıların sahip olmaları gereken en önemli becerilerden biridir. Böylece sosyal inovasyonu gerçekleştirmeleri mümkün olabilir.

\section{SONUÇ VE GELECEĞE YÖNELİK BAZI İPUÇLARI}

Günümüz sosyal koşullarında sosyal hizmetlere olan yoğun ilgi ve talep katlanarak büyümektedir. Böylece hükümetler, işletmeler ve kar amacı gütmeyen kuruluşların, her sektörün yaptıklarını etkin bir şekilde kullanmalarını sağlayacak yaratıcı çözümler bulmak için birlikte çalışması gerekecektir. Sosyal inovasyon ve girişimciliği ciddi bir şekilde gündemimize almak sosyal hizmet alanına ihtiyaç duyulan zor kararları alma sorumluluğunu yükleyecektir. Unutulmamalıdır ki ciddi düşünmek sadece sorunların kendilerini değil, hangi sorunların yenilikçi ve girişimci çabalara yanıt verebileceğini de kestirmektir (Okpych, 2017). Dolayısıyla sosyal inovasyon ve sosyal girişimcilik; sosyal çalışmacıların toplumsal sorunlara yönelik geliştirdiği bir dizi yeni strateji olarak teşvik edilmelidir çünkü toplum yararına yaratıcı ve yenilikçi çözüm yolları aramak sosyal çalışmacıların öncelikli misyonudur.

Ülkelerin gelişmişlik düzeyine göre sorunlar ve ihtiyaçlar şekillenirken bireylerin yaşam kalitelerine ve ülkelerin refah düzeylerine bağlı olarak hangi alanlarda sosyal inovasyona (Özmete, Akgül Gök, 2015) ve girişimciliğe ihtiyaç duyulduğu belirlenir. Özdemir ve Ar (2015)'a göre sosyal inovasyon çalışmalarında bulunması gerekli en önemli üç unsur arasında 'toplumun yaşam kalitesini artırmak için geliştirilecek sosyal hizmetler ve ürünler' (diğer ikisi; 'eğitim, sağlık, çevre ve ekonomi gibi sosyal alanlarda gelişme sağlama potansiyeli' ve 'sosyal değer yaratacak yeni fikirlerdir.') yer alırken yine hangi konularda sosyal inovasyon geliştirme kapasitesinin daha yüksek olduğu tartışıldığında sosyal hizmetler kendine ikinci sırada yer bulmaktadır. Sağlık, eğitim ve sosyal hizmetler gibi müşterek hizmetler için sürekli iyileştirmenin; sosyal inovasyonun ve sosyal girişimciliğin ortaya çıkışında daha geçerli olduğu ifade edilebilir (Austin vd., 2006).

Şu halde, sosyal hizmet alanında yeni kavram ve yöntemler; sosyal inovasyona ve girişimciliğe katkıda bulunan göç, sosyal medya ve teknoloji bağımlılığı gibi yeni sosyal sorunları, sosyal hizmet kurumlarının kendi yapı ve müdahale stratejilerini güncellemek zorunda olması gibi yeni eylemleri göz önüne alarak devam etmelidir. 
Bilimsel ve mesleki uygulamamızı iyileştirmek için yenilikçi akımları eleştirel düşünce süzgecinden geçirmemiz gerekmektedir. $\mathrm{O}$ zaman bu yenilikçi anlayışın bilimden yoksun olmayacağ 1 da açıkça görülecektir. Sonuçta sosyal inovasyan ve girişimcilik aslında bilimsel gelişmenin bir göstergesi olarak sosyal hizmette yönünü zaten çizmektedir. Özellikle yenilikçilik sosyal hizmette daha merkezi ve belirleyici bir rol üstlenmek zorundadır.

Son olarak bardağın boş tarafına da kısaca bakmak gerekir. Müracaatçı sistemine yönelik mevcut sosyal hizmet uygulamaları ve programları büyük oranda yenilik değil, ihtiyaç giderme, sorun çözme ve hizmet sunumu üzerine kuruludur. Kurumların müracaatçılarına sunduğu hizmetler; örgüt politikalarından, prosedürlere ve kültürel etkinliklere kadar her konudan etkilenir. $\mathrm{Bu}$ nedenle çoğu kurumda, sosyal çalışmacılardan yenilik istemek, onlardan muhtemelen çok az eğitim aldıkları, yapacakları zamanları olmadığı bir şey yapmalarını istemek olarak görülebilir. Kurumların yaklaşımları böyle olunca sosyal çalışmacılar arasında yeniliğe bakış açısı ve girişimci sorumlulukları konusunda karışı duygular ortaya çıkabilir (Traube $v d$., 2017). Sosyal hizmet akademisyenleri ve uygulayıcıları yeni kavramlara hoşgörü ile yaklaşmak yerine eski kuramları farklı boyutları ile çalışmalarına taşımaya devam da edebilirler. Birçok meslekte olduğu gibi sosyal hizmet mesleğinde de bu riski göz ardı etmemeliyiz. Bu durum sosyal hizmet literatürünü zenginleştirip değerli çalışmaların ortaya çıkmasına vesile olsa da yeni yönelimlere hızlı bir zemin hazırlama arayışından uzak olabilir. Dahası, yeni yönelimlerin diğer akademisyenler, uygulayıcılar ve diğer toplumsal öğelerle paylaşılması ya da onlar tarafindan kabul görmesi hala muğlak bir konudur. Bunların da farkında olmalıyız.

Son söz olarak şunu söyleyebiliriz: Sosyal inovasyonla birlikte değişim mesleğinden yenilikçi değişim mesleğine geçmeliyiz çünkü sosyal çalışmacıların alandaki yetkinliğini bugün ancak geliştirdikleri yeniliklerle ölçebilir ve geliştirebiliriz.

\section{KAYNAKÇA}

Akbaş, E., T. Tuncay (2005), “Ortak Sorumluluk Zamanı”, Radikal İki, 27/11/2005.

Atkins, P., M. Frederico (2017), "Supporting Implementation of Innovative Social Work Practice: What Factors Really Matter?. British Journal of Social Work, 47(6), 1723-1744.

Austin, J., H. Stevenson, J. Wei-Skillern (2006), "Social and Commercial Entrepreneurship: Same, Different, or Both?”, Entrepreneurship Theory and Practice, 30(1), 1-22.

Bahar, O.S. (2017), "A Promising Partnership: Uncovering the Middle Ground Between Social Innovation and Social Work Response to Dr. Marilyn 1. Flynn's Remarks", Research on Social Work Practice, 27(2), 131-133.

Baker, S., A. Mehmood (2015), "Social Innovation and the Governance of Sustainable Places", Local Environment, 20(3), 321-334. 
YILDIRIM, TUNCAY | The Role of Social Innovation and Social Entrepreneurship in the...

Cajaiba-Santana, G. (2014). "Social Innovation: Moving the Field Forward. A Conceptual Framework", Technological Forecasting and Social Change, 82, 42-51.

Choi, N., S. Majumdar (2014), "Social Entrepreneurship As An Essentially Contested Concept: Opening A New Avenue For Systematic Future Research", Journal of Business Venturing, 29(3), 363-376.

Defourny, J., M. Nyssens (2010), “Conceptions of Social Enterprise and Social Entrepreneurship in Europe and the United States: Convergences and Divergences”, Journal of Social Entrepreneurship, 1(1), 32-53.

Duyan, V. (2010), Sosyal Hizmet: Temelleri, Yaklaşımları, Müdahale Yöntemleri, (Birinci basım), Ankara: Sosyal Hizmet Uzmanları Derneği Genel Merkezi Yayınları.

Ersen, T.B., A. Ekmekçi (2013), "Sosyal Girişimcilik ve Türkiye", Stanford Social İnnovation Review Dergisi, 10.y1l Özel 6ay1s1, 6-8. https://www.anadoluvakfi.org.tr/upload/publications/pdfs/567eb73599f045.70852149 pdf, E.T.: 21.09.2018.

Flynn, M.L. (2017), “Science, Innovation, and Social Work: Clash or Convergence?”, Research on Social Work Practice, 27(2), 123-128.

Germak, A. (2017), If Steve Jobs Had Been A Social Worker. http://www.socialworker.com/feature-articles/practice/if-steve-jobs-had-been-a-socialworker/, E.T.: 01.02.2017.

Halvorsen, C. J. (2016), "Bridging Social Innovation and Social Work Balancing Science, Values, and Speed", Research on Social Work Practice, 27(2), 129-130.

Hofstede, G. (2001), Culture's Consequences: Comparing Values, Behaviours, Institutions and Organizastions Across Nations, (2nd ed.), London: Sage.

Hofstede, G. (2011), "Dimensionalizing Cultures: The Hofstede Model in Context". Online Readings in Psychology and Culture, 2(1), article 8.

Mair, J. ve Marti, I. (2006). "Social Entrepreneurship Research: A Source of Explanation, Prediction, and Delight", Journal of World Business, 41(1), 36-44.

Makarov, V., Y. Shimanovskaya, T. Tyapkina, M. Firsov, V. Sizikova, T. Rostovskaya, S. Kozlovskaya (2017), "Innovative Models of Social Activity and Their Adaptation to Social Work", Espacios, 38(43), 30-41.

Manzini, E. (2014), "Making Things Happen: Social İnnovation and Design”, Design Issues, 30(1), 57-66.

Martin, C.J., P. Upham (2016), "Grassroots Social Innovation and the Mobilisation of Values in Collaborative Consumption: A Conceptual Model”, Journal of Cleaner Production, 134, 204-213.

Minkov, M., G. Hofstede (2011), “The Evolution of Hofstede's Doctrine”, Cross Cultural Management: An International Journal, 18(1), 10-20.

Mulgan, G. (2006), “The Process of Social Innovation”, Innovations, 1(2), 145-162.

Mulgan, G., S. Tucker, R. Ali, B. Sanders (2007), Social Innovation: What it is, why it Matters and how it can be Accelerated, (Birinci basım), London: Basingstoke Press.

Hacettepe University Journal of Economics and Administrative Sciences |

Vol 37, Issue 1, 2019

186 
Nandan, M., M. London, T. Bent-Goodley (2015), "Social Workers As Social Change Agents: Social Innovation, Social Intrapreneurship, and Social Entrepreneurship", Human Service Organizations: Management, Leadership \& Governance, 39(1), 38-56.

Nandan, M., M. London, T. C. Blum (2014), "Community Practice Social Entrepreneurship: An Interdisciplinary Approach to Graduate Education”, International Journal of Social Entrepreneurship and Innovation, 3(1), 51-70.

Okpych, N.J. (2017), “A Historical Perspective on the Future of Innovation in Social Work", Research on Social Work Practice, 27(2), 150-153.

Özdemir, F., İ.M. Ar, (2015), "Sosyal Yenilik Üzerine Bir Alan Araştırması", Girişimcilik ve Inovasyon Yönetimi Dergisi, 4(1), 17-43.

Özmete, E. , F. Akgül Gök (2015), "Sürdürülebilir Kalkınma İçin Sosyal İnovasyon ve Sosyal Hizmet İlişkisinin Değerlendirilmesi”, Toplum ve Sosyal Hizmet, 26(2), 127-143.

Phillips, W., H. Lee, A. Ghobadian, N. O’Regan, P. James (2015), "Social Innovation and Social Entrepreneurship: A Systematic Review", Group \& Organization Management, 40(3), 428-461.

Plotinsky, Y.M. (2012). Theoretical and Empirical Models of Social Pro-Processes: Textbook for Higher Educational Institutions, Moscow: Publishing House of Logos Corporation.

Popescu, G. H. ve Gheorghe, H. (2015). "The Dynamics of Social Innovation Networks", Psychosociological Issues in Human Resource Management, 3(2), 77-82.

Rodriguez, M.Y., L. Ostrow, S.P. Kemp (2016), "Scaling up Social Problems Strategies For Solving Social Work's Grand Challenges", Research on Social Work Practice, 27(2), 139-149.

Schmitz, B., T. Scheuerle (2012), "Founding or Transforming? Social Intrapreneurship in Three German Christian-Based NPOs", ACRN Journal of Entrepreneurship Perspectives, 1(1), 13-36.

Stringfellow, E.J. (2017), "Applying Structural Systems Thinking to Frame Perspectives on Social Work Innovation”, Research on Social Work Practice, 27(2), 154-162.

Thomas, E.J. (1978). Generating Innovation in Social Work: The Paradigm of Developmental Research”, Journal of Social Service Research, 2(1), 95-115.

Traube, D.E., S. Begun, N. Okpych, M. Choy-Brown (2017), "Catalyzing Innovation in Social Work Practice”, Research on Social Work Practice, 27(2), 134-138.

Voorberg, W.H., V.J. Bekkers, J.M. Tummers (2015), “A Systematic Review of Co-creation and Co-production: Embarking on the Social İnnovation Journey”, Public Management Review, 17(9), 1333-1357.

Weerawardena, J., G.S. Mort (2006), "Investigating Social Entrepreneurship: A Multidimensional Model", Journal of World Business, 41(1), 21-35.

Zadek, S., S. Thake (1997), "Send in the Social Entrepreneurs", New Statesman, 126(4339), 31 32. 